\title{
MEDIASI PENAL DALAM PENYELESAIAN PERKARA KEKERASAN DALAM RUMAH TANGGA
}

\author{
Ni Kadek Ayu Ismadewi \\ Email: ismadewi81@yahoo.com \\ Pegawai Kejaksaan Negeri Kabupaten Sukoharjo \\ Widodo Tresno Novianto \\ Email: novianto@consultant.com \\ Hartiwiningsih \\ hartiwi@yahoo.com \\ Dosen Fakultas Hukum UNS Surakarta
}

\begin{abstract}
The purpose of this article to determine the judge's considerations using penal mediation in the settlement of Domestic Violence (KDRT) cases and its formulation in the future. This is a normative study with case approach, comparative approach and conceptual approach. The legal matterial of this research are primary legal matterial and secondary legal material with deductive analystic mind. Reffering the research above, Showed that there is a difference of judges consideration using the result of penal mediation in the form of peace between offender and victim who still have relationship of husband and wife in the settlement of case of domestic violence for offense. First, it is based on the benefit and recovering of the relationship of the offender and the victim, to the exclusion of the legalistic rules, so that the Judge arrives at the decision of the prosecution otherwise unacceptable. Second, based on expediency, but the legal process continues with the imposition of a conditional penalty. The existence of differences in consideration and judgment because the mediation of penal itself is not yet regulated in positive criminal law in Indonesia. However, with the starting point on the principle of benefit and the theory of pragmatic realism, the Judge should not worry or hesitate to use the results of peace in penal mediation as a way of resolving a domestic violence case by stopping the proceedings, although considered to be contrary to the principle of legal certainty. This has implications for the achievement of substantial justice for offender and victim, a quicker settlement of cases and avoid the accumulation of cases in the Court. Therefore the future needs to be formulated for mediation of penal entry into inseparable part in the procedure of settling the case of domestic violence, especially for offense complaints, ranging from the level of investigation, prosecution and court.
\end{abstract}

Keywords: Penal Mediation; Domestic Violence; Judge’s Decision

\begin{abstract}
Abstrak
Tujuan artikel ini adalah untuk mengetahui pertimbangan Hakim menggunakan mediasi penal dalam penyelesaian perkara Kekerasan Dalam Rumah Tangga (KDRT) dan formulasinya di masa mendatang. Penelitian ini merupakan studi normatif dengan pendekatan kasus, pendekatan komparatif dan pendekatan konseptual. Bahan hukum yang digunakan berupa bahan hukum primer dan bahan hukum sekunder dengan pola analisis deduktif. Hasil penelitian, menunjukkan bahwa adanya perbedaan pertimbangan Hakim menggunakan hasil mediasi penal berupa perdamaian
\end{abstract}


antara pelaku dan korban yang masih ada hubungan suami istri dalam penyelesaian perkara KDRT untuk delik aduan. Pertama, mendasarkan pada kemanfaatan dan pulihnya hubungan pelaku dan korban, dengan mengenyampingkan aturan yang bersifat legalistik, sehingga Hakim sampai pada putusan berupa penuntutan dinyatakan tidak dapat diterima. Kedua, mendasarkan pada kemanfaatan, namun proses hukum tetap dilanjutkan dengan penjatuhan pidana bersyarat. Adanya perbedaan pertimbangan dan penjatuhan putusan tersebut karena mediasi penal sendiri memang belum diatur dalam hukum positif pidana di Indonesia. Akan tetapi dengan bertitik tolak pada asas kemanfaatan dan teori realisme pragmatis, semestinya Hakim tidak khawatir atau ragu menggunakan hasil perdamaian dalam mediasi penal sebagai jalan penyelesaian perkara KDRT dengan menghentikan proses perkara, meski dianggap bertentangan dengan asas kepastian hukum. Hal tersebut berimplikasi pada tercapainya keadilan substansial bagi pelaku dan korban, penyelesaian perkara yang lebih cepat dan menghindari penumpukan perkara di Pengadilan. Kedepannya perlu diformulasikan agar mediasi penal masuk menjadi bagian tidak terpisahkan dalam prosedur penyelesaian perkara KDRT, khususnya untuk delik aduan, mulai dari tingkat penyidikan, penuntutan dan pengadilan.

Kata kunci: Mediasi Penal; Kekerasan Dalam Rumah Tangga; Putusan Hakim.

\section{A. Pendahuluan}

Salah satu bentuk perlindungan yang harus dimiliki setiap orang adalah perlindungan dari kekerasan baik dalam ranah personal, ranah komunitas maupun ranah negara. Perkembangan dewasa ini menunjukkan bahwa tindak kekerasan secara fisik, psikis, seksual maupun ekonomi justru banyak terjadi dalam ranah personal atau lingkup rumah tangga, dimana yang sering menjadi korban adalah perempuan dan anak. Jika dilihat dari karakteristiknya, KDRT merupakan jenis kekerasan yang memiliki sifat-sifat khas yakni dilakukan di dalam rumah, pelaku dan korban adalah anggota keluarga serta seringkali dianggap bukan sebagai bentuk kekerasan.

Ketentuan pidana dalam Undang-Undang PKDRT yang memberi perlindungan terhadap korban diatur dari Pasal 44 sampai pasal 53 dengan ancaman pidana berupa penjara atau denda. Beberapa dari ketentuan pidana tersebut merupakan delik aduan yaitu Pasal 44 ayat (4), pasal 45 ayat (2) dan pasal 46, sementara yang lainnya merupakan delik biasa. Terhadap perkara KDRT dengan delik aduan, sering diselesaikan secara damai di tingkat
Kepolisian dengan kewenangan diskresinya. Namun menjadi persoalan, bagaimana jika perkara tersebut sudah sampai pada tahap persidangan di pengadilan, baik untuk delik aduan maupun delik biasa, mengingat pengadilan tidak memiliki kewenangan untuk menghentikan proses suatu perkara meskipun ada perdamaian antara korban dengan pelaku. Sehingga putusan hakim yang menggunakan hasil mediasi penal berupa pencabutan delik aduan dan perdamaian antara pelaku dengan korban kemudian menyatakan penuntutan tidak dapat diterima, dianggap tidak memiliki dasar hukum yang pasti. Seperti dalam Putusan Pengadilan Negeri Sumber Nomor 336/ Pid.B/2012/PN.Sbr. tanggal 7 Agustus 2012 yang menyatakan bahwa penuntutan Penuntut Umum tidak dapat diterima dengan alasan telah terjadi perdamaian antara pelaku dan korban yang memiliki hubungan suami istri yang ditandai dengan pencabutan aduan oleh korban meski pencabutan tersebut sudah lewat waktu. Putusan tersebut menimbulkan pro dan kontra dikalangan hakim sendiri karena di satu sisi, putusan tersebut mengakomodir perdamaian dan pemulihan yang terjadi antara pelaku dengan korban, namun disisi lain 
putusan tersebut seakan-akan tidak memiliki landasan hukum yang kuat dalam penjatuhan putusannya. Sementara dalam beberapa putusan KDRT lainnya, Hakim lebih banyak menggunakan hasil mediasi penal hanya sebagai keadaan yang meringankan, sehingga terhadap si pelaku tetap dijatuhi pidana penjara, denda ataupun pidana bersyarat. Seperti Putusan Mahkamah Agung Nomor 307K/Pid.Sus/2010 dan Putusan Nomor 34/Pid.Sus/2012/PN. Pwr. Dari beberapa putusan KDRT tersebut, ternyata Hakim memiliki pertimbangan yang berbeda dalam menggunakan hasil mediasi penal berupa perdamaian dalam putusannya. Berdasarkan uraian tersebut, maka dalam tulisan ini akan dibahas mengenai apa pertimbangan hakim menggunakan hasil mediasi penal dalam penyelesaian perkara KDRT dan bagaimana formulasi mediasi penal dalam penyelesaian perkara KDRT dimasa mendatang.

\section{B. Metode Penelitian}

Penelitian ini penulis menggunakan jenis penelitian normatif, dengan menggunakan pendekatan kasus, pendekatan komparatif dan pendekatan konseptual. Sementara bahan penelitian yang peneliti gunakan adalah data sekunder, berupa bahan Hukum Primer dan Bahan Hukum Sekunder dengan teknik pengumpulan data adalah studi pustaka. Data pustaka tersebut dianalisa dengan metode deduktif sologisme menggunakan premis minor dan premis mayor dan penarikan kesimpulan.

\section{Hasil Penelitian Dan Pembahasan}

1. Pertimbangan Hakim Menggunakan Hasil Mediasi Penal dalam Perkara KDRT.

Perkara KDRT Nomor 336/ Pid.B/2012/PN.Sbr., Sudarta bin Wahid didakwa melakukan kekerasan fisik kepada istrinya korban Kamini Binti Sani, melanggar Pasal 44 ayat (1) Undangundang RI No. 23 Tahun 2004 tentang Penghapusan Kekerasan Dalam Rumah Tangga (UU PKDRT) atau dakwaan kedua Pasal 44 ayat (4) UU PKDRT.

Pasal 44 ayat (1) UU PKDRT berbunyi:

Setiap orang yang melakukan perbuatan kekerasan fisik dalam lingkup rumah tangga sebagaimana dimaksud dalam Pasal 5 huruf a dipidana dengan pidana penjara paling lama 5 (lima) tahun atau denda paling banyak Rp 15.000.000,00 (lima belas juta rupiah).

Sedangkan Pasal 44 ayat (4) berbunyi: Dalam hal perbuatan sebagaimana dimaksud pada ayat (1) dilakukan oleh suami terhadap isteri atau sebaliknya yang tidak menimbulkan penyakit atau halangan untuk menjalankan pekerjaan jabatan atau mata pencaharian atau kegiatan seharihari, dipidana dengan pidana penjara paling lama 4 (empat) bulan atau denda paling banyak Rp 5.000.000,00 (lima juta rupiah).

Pasal 44 ayat (1) merupakan delik biasa, sedangkan Pasal 44 ayat (4) adalah delik aduan. Korban mengajukan pengaduan kepada penyidik pada bulan Desember 2011. Namun kemudian korban mencabut pengaduannya tersebut dengan alasan telah terjadi penyelesaian secara musyawarah, kekeluargaan dan saling memaafkan serta pelaku dan korban sudah saling menyadari kesalahan masingmasing dan berjanji untuk membina rumah tangga yang harmonis kembali. Sementara batas waktu pencabutan pengaduan telah lewat waktu sebagaimana ketentuan dalam Pasal 75 KUHP. Namun oleh Hakim Pengadilan Negeri Sumber pencabutan tersebut dikabulkan dan 
selanjutnya menjatuhkan putusan akhir dalam perkara tersebut, meskipun belum memeriksa saksi maupun tuntutan dari Penuntut Umum, dengan menyatakan Penuntutan Penuntut Umum tidak dapat diterima. Putusan tersebut dikuatkan oleh Mahkamah Agung dengan Putusan Mahkamah Agung RI Nomor 2238 K/ Pid.Sus/2013 tanggal 5 Maret 2014. Sementara dalam Putusan Mahkamah Agung Nomor 307K/Pid.Sus/2010 dan Putusan Nomor 34/Pid.Sus/2012/ PN. Pwr., Hakim menggunakan hasil mediasi penal berupa perdamaian antara pelaku dan korban sebagai keadaan yang meringankan pidana bagi pelaku, dimana kemudian pelaku dijatuhi pidana bersyarat.

Menilik putusan perkara KDRT Nomor 336/Pid.B/2012/PN.Sbr tanggal 7 Agustus 2012 yang tidak menjatuhkan putusan berupa penghukuman, namun menghentikan proses perkara dengan menyatakan penuntutan tidak dapat diterima, Majelis Hakim Pengadilan Negeri Sumber dan Hakim Agung telah mengabaikan lewat waktunya batas pencabutan delik aduan oleh korban yang diatur selama tenggang waktu 3 (tiga) bulan sejak pengaduan diajukan, dengan dasar adanya mediasi penal yang menghasilkan perdamaian, permaafan dan telah bersatunya kembali Terdakwa dengan korban dalam rumah tangganya. Hakim Agung juga menyatakan bahwa Hakim agar tidak berfikir legalistik formalistik semata dan hanya berpedoman pada ketentuan hukum yang ada.

Putusan pengadilan tersebut dalam sistem peradilan pidana Indonesia yang bersifat sangat legalistik, dianggap bertentangan dengan undang-undang. Sikap hakim yang mengabaikan tenggang waktu pencabutan delik aduan dan mengakomodir hasil mediasi penal berupa perdamaian dan permaafan antara korban dan pelaku dengan menyatakan penuntutan Penuntut Umum tidak dapat diterima, tidak memiliki landasan hukum yang pasti. Karena karakteristik yang melekat pada hukum pidana beranggapan bahwa perkara pidana merupakan cerminan konflik antara warga negara dengan negara atau masyarakat, sehingga penyelesaiannya dilakukan melalui peradilan pidana yang sangat formal dan tidak dapat dikompromikan meskipun sudah ada perdamaian antara pelaku dengan korban (Salman Luthan, 2011: 1).

Hal ini berimbas pada sikap para hakim cenderung formalitas prosedural atau berpedoman pada pasal-pasal undang-undang semata meskipun hal tersebut tidak memberi rasa keadilan yang substansif dan manfaat bagi para pencari keadilan. Hal ini sebagaimana Putusan Mahkamah Agung Nomor 307K/ Pid.Sus/2010 dan Putusan Nomor 34/Pid. Sus/2012/PN. Pwr., yang menjatuhkan pidana bersyarat, karena Hakim masih berada dalam koridor aturan dengan tidak mengabaikan waktu pencabutan delik aduan dan hanya menggunakan hasil mediasi penal sebagai keadaaan yang meringankan pidana. Walaupun putusan tersebut memberi kemanfaatan bagi pelaku karena tidak harus menjalani pidana penjaranya dan juga korban yang telah bersatu dengan suaminya, namun tetap ada stigma bersalah yang ditanggung si pelaku dan disini hakim masih berorientasi menghukum dengan alasan tidak memiliki kewenangan menghentikan proses perkara dan Hakim harus menentukan hukum dalam bentuk penjatuhan putusan pemidanaan terhadap pelaku yang bersalah.

Ditinjau dari fungsinya, Hakim adalah manusia yang menjalankan penegakan hukum yang benar-benar 
menempati kedudukan yang penting dan menentukan (Satjipto Raharjo 2009: 1-2). Hakim sebagai pemutus suatu perkara menentukan nasib bahkan hidup mati seseorang, sebagaimana ungkapan "pengadilan sebagai benteng terakhir keadilan".

Pembentukan hukum yang terjadi karena undang-undang, dianggap sudah ketinggalan dan sudah tidak sesuai dengan keadaan ketika peristiwa itu terjadi, sehingga Hakim kemudian memiliki peran sentral membentuk hukum. Disini Hakim mencari norma non hukum, sekurangkurangnya non undang-undang (Pontang Moerad, 2005: 82). Karena Hakim dihadapkan pada kondisi yang tidak bisa menolak perkara dengan dalih tidak ada atau tidak jelas hukumnya. Selain itu, Undang-undang Nomor 48 tahun 2009 tentang kekuasaan kehakiman, Pasal 5 ayat (1) juga menyatakan bahwa, Hakim dan Hakim kostitusi wajib mengali, mengikuti dan memahami nilai-nilai hukum dan rasa keadilan yang hidup dalam masyarakat.

Hal tersebutlah yang mendorong pelaksanaan mediasi penal dalam penyelesaian perkara pidana, khususnya KDRT. Mediasi adalah salah satu bentuk penyelesaian sengketa dengan cara damai atau kesepakatan bersama sehingga tercapai solusi yang mengayomi kepentingan pihak bersengketa (winwin solution). Mediasi biasanya dikenal dalam perkara perdata, terkecuali terhadap Undang-Undang Nomor 11 Tahun 2012 Tentang Sistem Peradilan Pidana Anak (UU SPPA) melalui sistem diversi, tindak pidana ringan dengan ancaman denda atau tindak pidana aduan melalui pencabutan laporan perkara bersangkutan (Lilik Mulyadi, 2016, 13).
Penegakan hukum dalam perkara KDRT, hakim harus memperhatikan sifat khas dari kasus KDRT yakni dilakukan di dalam rumah, pelaku dan korban adalah anggota keluarga serta seringkali dianggap bukan sebagai bentuk kekerasan. Selain itu patut menjadi pertimbangan bahwa penjatuhan pidana berupa penjara bukanlah satu-satunya solusi terbaik dalam menyelesaikan tindak kejahatan, khususnya tindak kejahatan dengan "kerusakan" yang ditimbulkannya masih bisa di restorasi seperti dalam kasus KDRT, sehingga kondisi yang telah "rusak" dapat dikembalikan ke keadaan semula. Masyarakat mengharapkan manfaat dalam pelaksanaan atau penegakkan hukum. Hukum itu untuk manusia, maka pelaksanaan hukum atau penegakan hukum harus memberikan manfaat atau kegunaan bagi masyarakat. Hakim sebagai penegak hukum yang berhadapan langsung dengan empiris, fakta persidangan atau kenyataan yang terjadi, tidak dapat hanya berpedoman pada peraturan atau undang-undang semata (Luki Indrawati, 2007: 175).

Sejalan dengan hal tersebut, dalam teori realisme pragmatis, kemandirian dan kepeloporan hakim dalam menjalankan hukum terhadap kasus-kasus nyata, adalah merupakan hal terpenting karena sebagai pelaksana hukum dan langsung berhadapan dengan kenyataan, semestinya norma-norma hukum bagi hakim tidak lebih sekedar patokan saja agar normanorma tersebut dapat dipasangkan secara tepat dengan kebenaran realitas. Hakim bukanlah corong undang-undang. Sehingga kepeloporan hakim sangat menentukan apa yang merupakan hukum yang tepat, kini dan disini (Bernard L. Tanya, Yoan N. Simanjuntak, 2013:149150). Lebih lanjut Oliver Wendel Holmes, 
menyatakan bahwa aturan hukum bukan poros suatu keputusan yang berbobot karena aturan hukum tidak bisa diandalkan menjawab dunia kehidupan yang begitu kompleks, lagipula kebenaran riil bukan terletak dalam undang-undang, tetapi pada kenyataan hidup, sehingga hakim dengan kepekaan dan kearifannya harus memenangkan kebenaran meski dengan resiko mengalahkan aturan resmi (Bernard L. Tanya, Yoan N. Simanjuntak, 2013:150).

Putusan hakim yang baik sebaiknya mengandung beberapa aspek. Pertama, putusan tersebut merupakan gambaran proses kehidupan sosial sebagai bagian dari proses kontrol sosial. Kedua, merupakan penjelmaan dari hukum yang berguna untuk setiap orang maupun Negara. Ketiga, merupakan gambaran yang menciptakan keseimbangan antara kepentingan pelaku, korban dan masyarakat. Keempat, putusan tersebut merupakan kesadaran yang ideal antara hukum dan perubahan sosial. Kelima, harus bermanfaat bagi setiap orang baik pelaku maupun korban yang pada gilirannya bagi masyarakat. Keenam, putusan tersebut tidak menimbulkan konflik baru antara pelaku dan korban serta keluarganya (I Ketut Sudira, 2016, 75-76).

Perkara KDRT dengan Terdakwa Sudarta bin Wahid, putusan yang diambil oleh Hakim Pengadilan Negeri Sumber dan Mahkamah Agung RI didasarkan pada manfaat praktis bagi pelaku dan korban yang sudah berdamai melalui mediasi penal. Kenyataan bahwa pelaku dan korban sudah hidup rukun bersama lagi dalam rumah tangganya, merupakan faktor sosial yang tidak diabaikan oleh hakim, hingga akhirnya menjadikan realitas tersebut sebagai dasar utama menjatuhkan putusan mengabaikan batas waktu pencabutan delik aduan dan menggunakan hasil mediasi penal antara korban dan pelaku sebagai pertimbangan untuk menyatakan penuntutan tidak dapat diterima. Meskipun hal tersebut tidak memiliki kaidah hukum yang pasti, namun dari sisi keutamaannya, jauh sangat terpuji karena merefleksikan manfaat dan keadilan substansial bagi para pencari keadilan. Sehingga apabila seorang hakim mengenyampingkan norma-norma hukum (khususnya hukum pidana) atau asas legalitas dalam putusannya demi untuk mencapai keadilan dan manfaat yang sebesar-besarnya bagi pelaku dan korban serta masyarakat pada umumnya, maka hal tersebut tidak salah.

Teori realisme pragmatis menyatakan bahwa hukum itu bukan hanya yang tertulis dalam Undang-Undang atau ketentuan dan peraturan tertulis, namun lebih besar ditentukan oleh hakim di pengadilan yang pada umumnya didasarkan pada kenyataan di lapangan. Hakim punya otoritas untuk menentukan hukum ketika menjatuhkan putusan di pengadilan, meskipun putusannya itu dalam beberapa hal tidak selalu sama dengan apa yang tertulis dalam Undang-Undang atau aturan lainnya.

Jeremy Bentham menyatakan bahwa baik buruknya hukum harus diukur dari baik buruknya akibat yang dihasilkan oleh penerapan hukum itu, dimana suatu ketentuan hukum baru bisa dinilai baik, apabila akibat yang dihasilkan dari penerapannya adalah kebaikan (Lily Rasjidi dan I.B. Wyasa Putra, 1993: 79-80). Penanganannya didasarkan pada filsafat sosial, bahwa setiap warga masyarakat mencari kebahagiaan, dan hukum merupakan salah satu alatnya (Achmad Ali,2009: 272). Sementara dalam penegakan hukum pidana, kemanfaatan 
merupakan hal yang tidak dapat dilepaskan dari teori utilitarian karena penegakan hukum pidana mempunyai tujuan berdasarkan manfaat tertentu, bukan sekedar melakukan pembalasan kepada orang yang melakukan tindak pidana (Syaiful Bakhri, 2009:129). Kemanfaatan diartikan sebagai kebahagiaan (happiness). Hukum yang baik adalah hukum yang memberikan kebahagiaan bagi banyak orang. Sehingga dapat disimpulkan bahwa putusan hakim yang memberi banyak manfaat dan kebahagiaan kepada masyarakat, khususnya kepada pelaku dan korban, meskipun menyimpangi ketentuan undang-undang yang berlaku, maka putusan hakim tersebut telah memberikan keadilan yang substansial.

Putusan hakim yang mengabaikan batas waktu pencabutan delik aduan dan menggunakan hasil mediasi penal sebagai dasar pertimbangan untuk menyatakan penuntutan tidak dapat diterima tersebut juga tidak bertentangan dengan teori penegakan hukumnya yang selama ini menjadi patokan para hakim dalam menjatuhkan putusan. Karena kepastian hukum, tidak lagi sekedar kepastian legalitis, tetapi kepastian yang berkeadilan. Demikian juga soal kemanfaatan. Ia bukan lagi kemanfaatan tanpa patokan, tetapi kemanfaatan yang berkeadilan (yaitu memajukan nilai-nilai kemanusiaan) (Yovita A. Mangesti \& Bernard L. Tanya, 2014:74). Sehingga yang dituju sebenarnya bukanlah kepastian hukum hanya berdasar undang-undang semata ataupun manfaat tanpa dasar, namun kepastian dan kemanfaatan yang bertujuan memberi keadilan yang sesungguhnya, yaitu keadilan yang diharapkan oleh pelaku dan korban serta masyarakat.

Hakim-hakim perlu diberikan kewenangannya yang sesungguhnya sebagaimana dinyatakan dalam teori realisme pragmatis, bahwa Hakim punya otoritas untuk menentukan hukum ketika menjatuhkan putusan di pengadilan, meskipun putusannya itu dalam beberapa hal tidak selalu sama dengan apa yang tertulis dalam Undang-Undang atau aturan lainnya. Secara kasuistik hakim akan menerapkan aturan-aturan hukum demi terwujudnya keadilan sebagaimana tujuan hukum itu sendiri yakni mewujudkan keadilan bagi para pencari keadilan, utamanya untuk merealisasikan keadilan bagi masyarakat (Sudikno Mertokusuma, 2003: 77), Dan tentunya hal tersebut berkaitan dengan tujuan hukum menurut Jeremy Bentham yaitu ingin menjamin kebahagiaan yang terbesar bagi manusia dalam jumlah yang sebanyak-banyaknya.

\section{Formulasi Mediasi Penal dalam Penyelesaian Perkara KDRT di Masa Mendatang}

Penggunaan mediasi penal sebagai alternatif penyelesaian perkara pidana yang merupakan bagian dari proses peradilan pidana sangat dibutuhkan, sehingga dapat menjadi sarana penyelesaian yang sah dan hasil kesepakatannya bersifat mengikat terhadap para pihak, aparat hukum dan masyarakat (Umi Rozah, 2012:309). Prosedur mediasi penal tersebut wajib dilaksanakan mulai dari tahap penyidikan di Kepolisian hingga tahap persidangan di pengadilan.

Tahap formulasi merupakan tahap yang paling strategis dari upaya pencegahan dan penanggulangan kejahatan melalui kebijakan hukum pidana. Kesalahan/kelemahan kebijakan legislatif merupakan kesalahan strategis yang dapat menjadi penghambat upaya pencegahan dan penanggulanagan kejahatan pada tahap aplikasi dan eksekusi (Barda Nawawi Arief, 2001:75). Proses 
mediasi penal merupakan alternatif proses penyelesaian perkara pidana untuk mengatasi hal tersebut. Dengan menghindarkan seseorang masuk dalam Lembaga Pemasyarakatan maka di samping dapat menghindari stigmatisasi terpidana juga dapat menghemat biaya negara. Pertimbangan lain perlunya mediasi untuk tindak pidana KDRT khusus untuk delik aduan ini juga dapat didasarkan pada ancaman pidana yang bersifat alternatif antara pidana penjara atau denda ini memberikan peluang kepada hakim untuk tidak menjatuhkan pidana penjara, mengingat pidana penjara banyak madorot dari pada manfaatnya dan proses pembinaan di dalam lembaga pemasyarakatan belum dapat berfungsi secara baik. Dengan adanya ancaman yang bersifat alternatif ini kiranya dapat memberikan peluang atau dasar pertimbangan aturan secara informal, walaupun demikian dasar hukum formal perlu dipikirkan untuk masa yang akan datang (Liliana Tedjosaputro dan Krismiyarsi, 2012:61).

Pembaharuan hukum pidana juga harus dilakukan dengan pendekatan kebijakan karena pada hakikatnya pembaharuan hukum pidana hanya merupakan bagian saja dari kebijakan atau politik hukum pada umumnya dan khususnya bagian dari politik hukum pidana (criminal law/penal policy) (I Made Widnyana, 1995: 54-55). Ada beberapa ide yang melatar belakangi wacana penggunaan mediasi dalam masalah-masalah pidana. Ide mediasi penal ini ada yang dikaitkan dengan masalah pembaharuan hukum pidana (penal reform) dan ada yang dikaitkan dengan masalah pragmatisme. Latar belakang ide penal reform itu antara lain ide perlindungan korban, ide harmonisasi, ide restorative justice, ide mengatasi kekakuan/formalitas dalam sistem yang berlaku, ide menghindari efek negatif dari sistem peradilan pidana dan system pemidanaan yang ada saat ini, khususnya dalam mencari alternatif lain dari pidana penjara (alternative to imprisonment/ alternative to custody) (Barda Nawawi Arief, 2007). Latar belakang pragmatisme antara lain untuk mengurangi stagnasi atau penumpukan perkara, dan untuk penyederhanaan proses peradilan.

Hal tersebutlah kemudian yang mendorong pentingnya ditetapkan formulasi mediasi penal sebagai alternatif penyelesaian sengketa yang menjadi bagian dari proses yang wajib ditempuh dalam penyelesaian perkara KDRT untuk delik aduan, mengingat kekhasan yang melekat pada perkara KDRT tersebut. Adapun penentuan kebijakan-kebijakan formulasi mediasi penal dalam perkara KDRT yang harus diperhatikan oleh pembuat undang-undang meliputi: 1) Penentuan Formulasi Pengertian Yuridis Mediasi Penal. 2) Kebijakan Penentuan Asas-Asas Mediasi Penal, dimana asasasas mediasi penal dalam perkara KDRT yang perlu dirumuskan meliputi: asas bebas dan suka rela, kebebasan para pihak untuk menarik diri selama proses mediasi, asas kerahasiaan (Confidential). 3) Kebijakan Penentuan Tindak Pidana Yang Dapat Dimediasi, berupa ancaman pidana yang rendah paling lama 5 (lima) tahun atau denda, merupakan delik aduan baik absolut maupun relative, dan bukan merupakan pengulangan atau residivis. 4) Jangka waktu mediasi penal, yakni tentang daluarsanya kasus KDRT yang dapat dimediasi serta lamanya proses mediasi.

Prinsip umum dalam mediasi penal sebagai berikut: 1) Penyelesaian masalah dengan mediasi hanya dapat berlangsung apabila para pihak menyetujui untuk 
melakukan mediasi, 2) Segala macam hal yang dibicarakan dalam mediasi penal bersifat rahasia dan tidak akan digunakan sesudah itu, kecuali dengan persetujuan para pihak, 3) Mediasi penal harus dapat disediakan dalam setiap tahapan proses dalam sistem peradilan pidana, 4) Pelaksanaan mediasi penal haruslah diberi otonomi yang cukup dalam sistem peradilan pidana. (Laely Wulandari, 2008).

Sistem mediasi penal yang digunakan di beberapa negara seperti Belanda, Australia dan Amerika Serikat dapat digunakan sebagai rujukan. Dalam KUHP Belanda yang memiliki system hukum sama dengan Indonesia, mengatur tentang permaafan atau pengampunan (rechterlijk pardon) dari hakim karena telah terjadinya perdamaian antara korban dan pelaku, sehingga pelaku tidak perlu dijatuhi pidana lagi. Sementara di Amerika Serikat, terdapat sistem plea bargaining yang merupakan bagian dari system penegakan hukum (criminal justice system) yang merupakan salah satu prosedur formal dan legal. Sedangkan Australia menganut family law untuk menyelesaikan perkara KDRT.

Ada beberapa model mediasi penal seperti disebutkan dalam Explanatory memorandum dari Rekomendasi Dewan Eropa No. R (99) 19 tentang Mediation in Penal Matters (Barda Nawawi Arief, 2010:7-12) sebagai berikut :

1) Model informal mediation

Model ini dilaksanakan oleh personil peradilan pidana (criminal justice personnel) yaitu dapat dilakukan oleh Jaksa Penuntut Umum, Polisi atau Hakim dengan mengundang para pihak untuk melakukan penyelesaian informal dengan tujuan, tidak melanjutkan penuntutan apabila tercapai kesepakatan;
2) Model Traditional village or tribal moots

Menurut model ini, seluruh masyarakat bertemu untuk memecahkan konflik kejahatan di antara warganya.

3) Model victim-offender mediation Mediasi antara korban dan pelaku merupakan model yang paling sering ada dalam pikiran orang. Model ini melibatkan berbagai pihak yang bertemu dengan dihadiri oleh mediator yang ditunjuk. Mediasi ini dapat diadakan pada setiap tahapan proses, baik pada tahap kebijaksanaan polisi, tahap penuntutan, tahap pemidanaan atau setelah pemidanaan.

4) Model Reparation negotiation programmes

Model ini semata-mata untuk menaksir/ menilai kompensasi atau perbaikan yang harus dibayar oleh pelaku tindak pidana kepada korban, biasanya pada saat pemeriksaan di pengadilan. Program ini tidak berhubungan dengan rekonsiliasi antara para pihak, tetapi hanya berkaitan dengan perencanaan perbaikan materiel. Dalam model ini, pelaku tindak pidana dapat dikenakan program kerja agar dapat menyimpan uang untuk membayar ganti rugi/ kompensasi.

5) Model Community panels or courts Model ini merupakan program untuk membelokkan kasus pidana dari penuntutan atau peradilan pada prosedur masyarakat yang lebih fleksibel dan informal dan sering melibatkan unsur mediasi atau negosiasi.

6) Model Family and community group conferences

Model ini telah dikembangkan di Australia dan New Zealand, yang melibatkan partisipasi masyarakat dalam sistem peradilan pidana. Tidak 
hanya melibatkan korban dan pelaku tindak pidana, tetapi juga keluarga pelaku dan warga masyarakat lainnya, dengan harapan menghasilkan kesepakatan yang komprehensif dan memuaskan korban serta dapat membantu untuk menjaga sipelaku keluar dari kesusahan/persoalan berikutnya.

Berbagai model mediasi penal yang telah diterapkan di berbagai Negara, maka penulis mengadopsi dari berbagai sumber terkait konsep mediasi penal yang dapat digunakan dalam proses penyelesaian perkara KDRT untuk delik aduan baik tingkat penyidikan, penuntutan maupun persidangan di pengadilan (Lilik Mulyadi, 2016:76-78 dan I Ketut Sudira, 2016:132-138).

Mediasi pada tahap penyidikan merupakan kombinasi model mediasi informal mediation, victim-offender mediation dan reparation negotiation programmes. Pada tahap ini dapat ditetapkan cara kerja mediasi penal sebagai berikut: 1) Penyidik mempelajari kasus atau tindak pidana KDRT yang dilakukan oleh pelaku dengan kriteriakriteria tertentu, menawarkan mediasi kepada pelaku dan korban, 2) Mediasi penal harus dilakukan secara suka rela dari semua pihak yang terlibat, 3) Mediasi dilakukan secara rahasia sesuai dengan prinsip confidentiality, 4) Pelaku dan korban dipertemukan untuk mencari solusi yang saling menguntungkan, 5) Mediator harus mempunyai sertifikasi dan terlatih sebagai mediator, 6) Jika dicapai kesepakatan dalam mediasi, maka mediator memberitahukan kepada penyidik. Namun bila gagal, maka proses perkara dilanjutkan,7) Hasil kesepakatan mediasi penal merupakan putusan final, sehingga merupakan alasan penghapus penuntutan.
Mediasi penal perkara KDRT di tahap penuntutan merupakan kombinasi antara bentuk Victim-Offender Mediation dan Reparation Negotiation Programme. Adapun pelaksanaan mediasi penal pada tahap penuntutan dapat digambarkan sebagai berikut: 1) Jaksa penuntut umum mempelajari tindak pidana KDRT yang dilakukan oleh pelaku berdasarkan kriteria-kriteria tertentu, lalu dapat menawarkan mediasi kepada korban dan pelaku tindak pidana, 2) Mediasi dilakukan berdasarkan persetujuan secara suka rela dari pelaku dan korban tindak pidana, 3) Jaksa penuntut umum dapat berposisi sebagai mediator maupun dapat melakukan penunjukan mediator dari luar yang bersertifikasi, 4) Mediator mempertemukan pihak pelaku dan korban tindak pidana yang pelaksanaannya dilakukan secara rahasia, 5) Jika mediasi penal gagal, maka perkara pidana akan dilanjutkan dengan proses pemeriksaan di sidang pengadilan dengan dilakukan penuntutan terhadap tindak pidanannya. 6) Jika mediasi mencapai kesepakatan damai yang diterima oleh semua pihak, maka akta kesepakatan berlaku sebagai putusan yang final dan tidak dapat diadakan penuntutan, sehingga dapat berfungsi sebagai alasan penghapus penuntutan.

Mediasi penal dalam tahap pengadilan jika mencapai kesepakatan maka hasilnya dapat digunakan sebagai alasan untuk menghapuskan menjalankan pidana bagi pelaku tindak pidana. Mediator pada tahap ini bisa dilakukan oleh hakim ataupun mediator dari luar pengadilan yang telah mendapatkan sertifikasi dan pelatihan. Mediasi ini adalah gabungan dari model Victim-Offender Mediation dan Reparation Negotiation Programmes. Adapun pelaksanaan mediasi ini adalah sebagai berikut: 1) Hakim setelah 
mempelajari kasus dan tindak pidana KDRT yang dilakukan oleh terdakwa, dapat menawarkan mediasi penal sebagai alternatif penyelesaian perkara dengan perdamaian para pihak, 2) Jika para pihak menyetujui, maka diadakan persetujuan secara suka rela untuk mengikuti penyelesaian perkara dengan cara mediasi, 3) Hakim dapat bertindak sebagai mediator ataupun dengan mediator di luar pengadilan yang telah memenuhi syarat dan bersertifikasi, 4) Mediasi penal dilakukan berdasarkan prinsip rahasia, 5) Jika mediasi tidak mencapai kesepakatan (gagal) maka proses pemeriksaan di muka pengadilan akan dilanjutkan sebagaimana mestinya. Sebaliknya jika berhasil, maka hasil kesepakatan yang dituangkan dalam akta kesepakatan menjadi berkekuatan tetap sebagaimana putusan pengadilan dan bersifat final, sehingga pelaku tidak dapat dituntut dan diadili kembali dalam proses peradilan pidana.

Mekanisme penyelesaian perkara KDRT mulai tingkat penyidikan, penuntutan dan persidangan di pengadilan sebagaimana disebutkan diatas, yang merupakan kombinasi model informal mediation, victim-offender mediation dan reparation negotiation programmes, menekankan pada adanya ganti kerugian, namun karena perkara KDRT memiliki sifat khas berupa adanya hubungan keluarga (suami istri) antara pelaku dengan korban, sehingga tidak menutup kemungkinan dalam mediasi penal tercapai perdamaian antara pelaku dan korban untuk kembali sama-sama membina rumah tangga tanpa harus ada ganti kerugian kepada korban. Sehingga konsep mediasi penal dalam penyelesaian perkara KDRT untuk tingkat penyidikan, penuntutan dan persidangan di pengadilan patut memperhatikan pendekatan restoratif yang lebih respek terhadap etika-etika mediasi. Di dalam mediasi ini yang dijadikan pertimbangan adalah apa yang dikatakan oleh para pihak bukan pada dokumen-dokumen hukum yang ada. Titik tekan mediasi dalam perkara KDRT adalah pada komunikasi. Moderator tidak mengarahkan hanya bersifat membantu untuk merumuskan tujuan sendiri dalam upaya penyelesaian konflik (Eddy Rifa, 2003:153).

Hakim sebagai manusia yang menjalankan penegakan hukum benarbenar menempati kedudukan yang penting dan menentukan (Satjipto Rahardjo, 2009: 1-2). Sebuah putusan Hakim, selain mengadili dan memberikan keadilan bagi pihak-pihak yang berperkara dan memberikan penilaian bagi pihak-pihak yang berperkara, ada fungsi lain yang harus tercermin dalam putusan Hakim tersebut meliputi: fungsi pendidikan hukum bagi masyarakat, fungsi pembaharuan hukum melalui proses penemuan hukum dan penyelesaian konflik secara luas (Muladi, 2005:312).

Perdamaian mempunyai pengaruh bagi hakim dalam mengambil sebuah keputusan. Besar kecilnya peran perdamaian dalam putusan tergantung keberanian Hakim dalam mengambil putusan, disaat perdamaian yang merupakan rasa keadilan para pihak bertentangan dengan kepastian hukum dalam mengadili suatu perkara. Apabila dalam kebijakan penanggulangan kejahatan digunakan upaya/sarana hukum pidana (penal), maka kebijakan hukum pidana harus diarahkan pada tujuan dari kebijakan sosial (social policy) yang terdiri dari kebijakan/upaya-upaya untuk kesejahteraan social (social welfare policy) dan kebijakan/upaya-upaya untuk melindungi masyarakat (social defence policy). Oleh karena itu dapat dikatakan bahwa tujuan akhir atau tujuan utama 
dari politik kriminal adalah perlindungan masyarakat untuk mencapai kesejahteraan (Barda Nawawi Arief, 2001:73-74).

Penyelesaian perkara KDRT untuk delik aduan melalui mediasi penal yang menjadi bagian tidak terpisahkan dalam sistem peradilan pidana, membuat para penegak hukum baik Polisi, Penuntut Umum dan terutamanya hakim, memiliki dasar hukum yang jelas untuk melakukan mediasi penal antara pelaku dan korban, dan selanjutnya menggunakan hasil mediasi penal tersebut sebagai pertimbangan menghentikan penuntutan terhadap pelaku.

\section{Simpulan}

1. Bahwa pertimbangan Hakim mengabaikan ketentuan batas waktu pencabutan delik aduan dalam perkara KDRT dengan alasan telah adanya perdamaian dalam mediasi penal antara pelaku dan korban dan kemudian menjatuhkan putusan berupa penuntutan Penuntut Umum tidak dapat diterima, merupakan putusan yang memiliki dasar teori realisme pragmatis dan kemanfaatan, dimana hakim bebas menentukan hukum yang sesuai dengan kenyataannya dan tidak hanya berpedoman pada undang-undang semata, yang mengedepankan kemanfaatan bagi para pihaknya dan memberikan keadilan substansial, dibandingkan putusan pemidanaan yang hanya berorientasi pada keadilan prosedural.

2. Bahwa formulasi mediasi penal dalam penyelesaian perkara KDRT di masa mendatang patut diterapkan menjadi bagian dalam proses peradilan pidana mulai dari tingkat penyidikan, penuntutan dan persidangan di pengadilan dengan memperhatikan prinsip dan kebijakan formulasinya karena lebih memberi keadilan dan kemanfaatan bagi pelaku dan korban yang memiliki ikatan dalam rumah tangga.

\section{E. Saran}

1. Hakim harus berani bersikap bebas, tanpa selalu tunduk pada ketentuan undangundang yang bersifat positivistic dalam memutus perkara KDRT dengan dasar telah tercapai perdamaian dalam mediasi penal, sehingga akan memberi manfaat yang sebesar-besarnya dan rasa keadilan yang lebih substansial kepada para pihak.

2. Konsep mekanisme mediasi penal yang masuk menjadi bagian tidak terpisahkan dalam sistem peradilan pidana, khususnya dalam penyelesaian perkara KDRT agar segera dilaksanakan sehingga penyelesaian perkara KDRT menjadi lebih cepat, sederhana dan murah.

\section{F. Daftar Pustaka}

\section{Buku}

Achmad Ali. 2009. Menguak Teori Hukum (legal Theory) dan Teori Peradilan (judicial prudence). Jakarta: Kencana Prenadamedia Group.

Barda Nawawi Arief. 2001. Masalah Penegakan Hukum dan Kebijakan Penanggulangan Kejahatan. Bandung: PT.Citra Aditya Bakti.

. 2010. Mediasi Penal Penyelesaian Perkara Di Luar Pengadilan. Semarang: Pustaka Magister.

Bernard L. Tanya, Yoan N. Simanjuntak, Markus Y. Hage. 2013. Teori Hukum (Strategi Tertib Manusia Lintas Ruang Generasi). Yogyakarta: Genta Publishing.

Eddy Rifa. 2003. "Pluralisme Hukum dan Penegakan Hukum Pidana di Dalam Masyarakat," dalam Bunga Rampai Hukum dan Kemajemukan Budaya, E.K.M. Masinambow, Yayasan Obor Indonesia. 
I Made Widnyana. 1995. Bunga Rampai Pembangunan Hukum Indonesia. Bandung: Ersco.

I Ketut Sudira. 2016. Mediasi Penal Perkara Penelantaran Rumah Tangga. Yogyakarta: UII Press.

Lily Rasjidi dan I.B. Wyasa Putra. 1993. Hukum Sebagai Suatu Sistem. Bandung: Remaja Rosdakarya.

Lilik Mulyadi. 2016. Implementasi Mediasi Penal Sebagai Perwujudan NilaiNilai Pancasila Guna Mendukung Supremasi Hukum Dalam Rangka Pembangunan Nasional. Yogyakarta: Genta Publihsing.

Pontang Moerad. 2005. Pembentukan Hukum Melalui Putusan Pengadilan Dalam Perkara Pidana. Cetakan pertama. Bandung: Alumni.

Satjipto Raharjo. 2009. Penegakan Hukum Suatu Tinjauan Sosiologis. Yogyakarta: Genta Publishing.

Sudikno Mertokusuma. 2003. Mengenal Hukum Suatu Pengantar. Yogyakarta: Liberty.

Syaiful Bakhri. 2009. Pidana Denda dan Korupsi. Yogyakarta: Total Media.

Umi Rozah. 2012. Konstruksi Politik Hukum Mediasi Penal sebagai Alternatif Penyelesaian Perkara Pidana, Dalam Hukum Pidana Dalam Perspektif. Denpasar: Pustaka Larasan.

Yovita A. Mangesti \& Bernard L. Tanya. 2014. Moralitas Hukum. Yogyakarta: Genta Publishing.

\section{Jurnal}

Luki Indrawati. 2007. "Rekonstruksi Legal Reasoning Hakim Sudut Pandang Epistimologis Terhadap Logika
Hukum", Jurnal Media Hukum, Volume 14 No. 3 November 2007. Yogyakarta: Universitas Muhammadiyah Yogyakarta.

Laely Wulandari. 2008. "Kebijakan Penanganan Kekerasan Dalam Rumah Tangga Melalui Mediasi Penal", Jurnal Law Reform, Volume 4, No. 1, Tahun 2008, Semarang: Universitas Diponegoro.

Liliana Tedjosaputro. 2012. "Kebijakan Penanggulangan Kejahatan Melalui Mediasi Penal sebagai alternative Penyelesaian Tindak Pidana KDRT", Jurnal Kriminologi Indonesia, Vol. 8 No.1 Mei 2012, Jakarta:Universitas Indonesia.

\section{Peraturan perundangan}

Undang-Undang Nomor 48 Tahun 2009 tentang Kekuasaan Kehakiman

Undang-Undang Nomor 23 Tahun 2004 tentang Penghapusan Kekerasan Dalam Rumah Tangga.

\section{Putusan}

Putusan Pengadilan Negeri Sumber Nomor 336/Pid.B/2012/PN.Sbr

Putusan Mahkamah Agung RI nomor 2238K/ Pid.Sus/2013

Putusan Mahkamah Agung RI Nomor 307K/ Pid.Sus/2010.

Putusan Pengadilan negeri Purworejo Nomor 34/Pid.Sus/2012/PN. Pwr.

\section{Makalah}

Salman Luthan. 2011. "Mediasi Penal: Dalam Sistem Peradilan Pidana", Makalah disampaikan pada diskusi Mediasi Penal dalam Sistem Peradilan Pidana Indonesia yang diselenggarakan oleh Mahkamah Agung RI di Semarang, 2527 Mei 2011. 